\title{
Effect of ewe stocking rate in spring on subterranean clover persistence and lamb liveweight gain
}

\author{
S. ATES ${ }^{1}$, H.E. BROWN², R.J. LUCAS ${ }^{1}$, M.C. SMITH ${ }^{1}$ and G.R. EDWARDS ${ }^{1}$ \\ ${ }^{I}$ Agriculture Group, Agriculture and Life Sciences Division, Field Service Centre, Lincoln University, Lincoln 7647 \\ ${ }^{2}$ Crop \& Food Research, Private Bag 4704, Christchurch \\ edwardsg@lincoln.ac.nz
}

\begin{abstract}
Liveweight gain of ewes and lambs and subterranean clover reproduction were measured in tall fescuesubterranean clover pastures on a dry, stony soil stocked at 10 (low) and 20 (high) ewes and their twin lambs/ha over 46 days in spring 2005. Lambs grew at $374 \mathrm{~g} /$ day at the low stocking rate and $307 \mathrm{~g} /$ day at the high stocking rate, meaning final liveweight was $3.1 \mathrm{~kg}$ higher at the low stocking rate. However, lamb liveweight gain/ha/ day was greater at the high $(12.3 \mathrm{~kg} /$ ha/day $)$ than the low $(7.5 \mathrm{~kg} / \mathrm{ha} /$ day) stocking rate. Ewes gained $2.2 \mathrm{~kg}$ at the low stocking rate and lost $4.9 \mathrm{~kg}$ at the high stocking rate, with most liveweight loss occurring in the second half of the grazing period when moisture stress restricted subterranean clover growth. There were $62 \%$ fewer burrs/ $\mathrm{m}^{2}$ at the high than the low stocking rate. For both stocking rates, inadequate seed production resulted in inadequate seedling numbers in the following autumn ( 285 and 223 seedlings $/ \mathrm{m}^{2}$ at low and high stocking rate, respectively). The results show high lamb liveweight gains can be obtained on subterranean clover pastures, but, in a drier than average spring, selective grazing of the clover may result in poor subterranean clover seed production and reduced seedling numbers in the following the autumn.
\end{abstract} Keywords: liveweight gain, seed production, sheep grazing, stocking rate, subterranean clover, tall fescue

\section{Introduction}

The annual legume subterranean clover (Trifolium subterraneum) is a valuable pasture legume in dry east coast regions of New Zealand, particularly in areas that are too dry to support white clover. Persistence and productivity of subterranean clover is dependent on adequate spring flowering and seed set, followed by seedling re-establishment in autumn (Smetham 2003). Reduced seed production in subterranean clover will adversely affect seedling populations the following autumn. In turn, this will affect the amount of clover herbage on offer to lambing ewes in the following spring.

Flowering of subterranean clover occurs with the main flush of rapid herbage production of the species in spring, and coincides with high feed demand from lactating ewes. This situation presents challenges to grazing managers of how to effectively manage their pastures to achieve the conflicting objectives of seed production and livestock performance. During moist spring conditions, experienced farmers recommend set stocking of subterranean clover dominant pastures so that a pasture mass of $2000 \mathrm{~kg} \mathrm{DM} / \mathrm{ha}$ is maintained to ensure adequate seed production (Costello \& Costello 2003). However, when spring rainfall is less than average, ewes and lambs may rapidly reduce pasture to less than $1400 \mathrm{~kg} \mathrm{DM} / \mathrm{ha}$, and differential grazing of paddocks may then be necessary. Grazing intensity can then be increased to sacrifice subterranean clover seed production in paddocks known to have high seed reserves while it may be possible to graze newly established pastures less intensively so that moderate seed production of subterranean clover is achieved.

Decisions for differential management of paddocks to protect annual clover populations are not well supported by quantified data. As we do not know when "hard grazing" is "too hard", we set out to investigate the possibility of developing guidelines for subterranean clover management in relation to seed production and the maintenance of lamb growth rates. This was done by grazing a tall fescue-subterranean clover pasture on a dry stony soil in Canterbury with lactating ewes and their twin lambs at a conservative 10 ewes/ha compared with a high stocking rate of 20 ewes/ha.

The specific objectives of the study were to quantify the effect of low versus high stocking rates during the flowering stage of the subterranean clover life cycle on: 1. lamb and ewe liveweight gain;

2. subterranean clover reproductive performance.

\section{Materials and methods Experimental site}

The experiment was conducted in a 4 ha paddock at Ashley Dene, the Lincoln University dryland research farm located near Lincoln, Canterbury. The soil type is a Lismore very stony silt loam. Soil tests taken at the start of the experiment gave: $\mathrm{pH}$ (in water) $=6.4$, Olsen $\mathrm{P}=$ $28, \mathrm{Ca}=10$ m.e. $/ 100 \mathrm{~g}, \mathrm{~K}=20$ m.e. $/ 100 \mathrm{~g}, \mathrm{Mg}=20$ m.e. $/$ $100 \mathrm{~g}, \mathrm{Na}=6$ m.e. $/ 100 \mathrm{~g}$ and $\mathrm{S}=6$ m.e. $/ 100 \mathrm{~g}$. Ashley Dene has a mean annual rainfall of $629 \mathrm{~mm}$. Rainfall and air temperatures at Ashley Dene during the experimental period (August 2005 to April 2006) are given in Figure 1 . It is noteworthy that high rainfall occurred soon after the grazing trial was started on 22 September and that 
Figure 1 Rainfall (mm, bars) and air temperature $\left({ }^{\circ} \mathrm{C}\right.$, line) recorded at Ashley Dene during the experimental period.

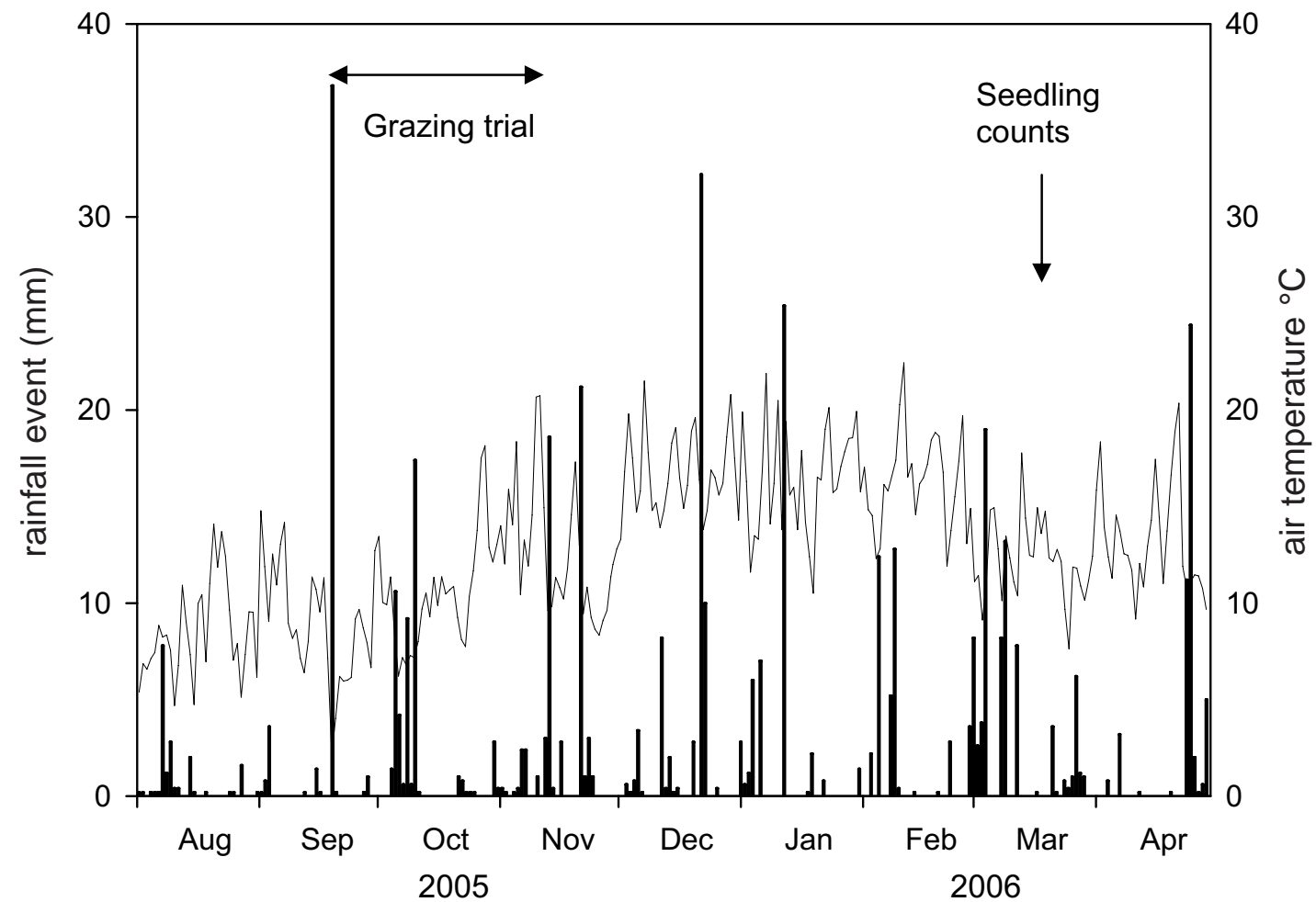

there was little rainfall in the second half of the grazing period. The 4 ha paddock was sown with a mixture of tall fescue (Festuca arundinacea, cv. Advance, $10 \mathrm{~kg} /$ ha) and Caucasian clover (T. ambiguum cv. Endura, 8 $\mathrm{kg} / \mathrm{ha}$ ) and white clover (T. repens cv. Demand, $2 \mathrm{~kg} / \mathrm{ha}$ ) on 1 October 2002. The tall fescue establishment was poor and the population density was low (32 plants $\left./ \mathrm{m}^{2}\right)$ in mid May 2005. The paddock was direct drilled with subterranean clover (cv. Woogenellup, $5 \mathrm{~kg} / \mathrm{ha}$ and cv. Karridale, $5 \mathrm{~kg} / \mathrm{ha}$ ) on 17 April 2004. The paddock was grazed laxly in the first spring (2004) to encourage the subterranean clover to set sufficient seed to allow valid experiments during 2005. Before the start of the grazing trial, the botanical composition was scored by visual estimates (\% cover) in eight $1 \mathrm{~m}^{2}$ quadrats in each of the eight paddocks. Based on this, the percentage composition was: $34.8 \%$ tall fescue, $4.7 \%$ perennial clovers, $39.6 \%$ subterranean clover, $4.9 \%$ other annual legumes (mainly cluster clover, T. glomeratum), $0.9 \%$ dicot weed, $8.6 \%$ annual grass weeds, $1.5 \%$ litter and $5.0 \%$ bare ground.

\section{Spring 2005 grazing treatment}

The 4 ha paddock was fenced into four 1 ha replicate paddocks which were further split in half to provide eight 0.5 ha plots. One of the 0.5 ha plots in each replicate was allocated to a low stocking rate $(10$ ewes +20 twin lambs/ha) and one to a high stocking rate ( 20 ewes +40 twin lambs/ha) providing four replicates of the two grazing treatments. Both ewes (mean liveweight $=70$ $\mathrm{kg}$ ) and lambs (mean liveweight $=7.7 \mathrm{~kg}$ ) were Coopworths. Lambs were 14 days old \pm 3 days at the start of trial. Treatments were not balanced for lamb sex. The ewes and their lambs grazed continuously on the plots for 46 days from 22 September to 7 November 2005.

\section{Measurements}

All ewes and lambs were weighed at the start (22 September) and end ( 7 November) of the trial. Liveweight gain per animal and per ha was then calculated. Botanical composition was recorded by visual estimates ( $\%$ cover) of all pasture species in eight randomly located $1 \mathrm{~m}^{2}$ quadrats in each of the eight paddocks on 14 November 2005, 1 week after ewes were removed. Pasture height was measured with a rising plate meter on 17 October, 23 October, 31 October and 7 November 2005. At this stage the pasture represented a mosaic with patches of tall fescue within a background of subterranean clover. Sampling for pasture height was thus stratified, with a total of 40 rising plate pasture heights taken in tall fescue and subterranean clover patches, respectively, in each of the eight paddocks. On 11 November, once sheep were 
removed from the plots, subterranean clover plants were cut at ground level from eight randomly placed $0.2 \mathrm{~m}^{2}$ quadrats in each of the eight paddocks for morphological measurements. The number of subterranean clover plants in each quadrat was counted and then measurements were made on each plant of the number of runners, runner length, number of burrs and number of flowers. On 16 February 2006, approximately 50 burrs were collected from the dry soil surface of each plot. Seeds were extracted and a mean seed weight was determined. Seedlings of subterranean clover were counted in ten $0.1 \mathrm{~m}^{2}$ quadrats in each of the eight paddocks on 17 March 2006 after a flush of germination from early March rainfall.

Data were analysed as a one way ANOVA of a randomised block design. Percentage composition data were arcsine square-root transformed before ANOVA.

\section{Results}

Lamb liveweight gain per animal was greater at the low than high stocking rate (Table 1) with final lamb liveweight $3 \mathrm{~kg}$ greater at the low $(24.8 \mathrm{~kg})$ than the high (21.8) stocking rate. Lamb liveweight gain/ha/day was greater at the high than the low stocking rate (Table 1).
Ewe liveweight gain per animal was greater at low than high stocking rate (Table 1) with ewes gaining $2.2 \mathrm{~kg}$ at the low stocking rate and losing $4.9 \mathrm{~kg}$ at the high stocking rate.

When grass and clover height were first recorded separately on 17 October 2005, tall fescue and subterranean clover patches were both shorter $(\mathrm{P}<0.05)$ at the high than the low stocking rate (Fig. 2). These differences in height persisted until the end of the grazing period. The percentage cover of subterranean clover and litter were lower, and bare ground was higher, at the high than the low stocking rate at the end of the grazing period (Table 2). The percentage cover of the other sward components was unaffected by stocking rate (Table 2).

There was less than half the number of burrs $/ \mathrm{m}^{2}$ at the high than the low stocking rate due mainly to half as many burrs/plant being present at the high stocking rate (Table 3). Plant dryweight and runner length at the high stocking rate were both around half that of the low stocking rate (Table 3). The 1000 seed weights at the high stocking rate were $80 \%$ of those at the low stocking rate (Table 3). The 1000 seed weights of 3 to $5 \mathrm{mg}$ were less than half the weights of the Woogenellup and

Table 1 The effect of low (10 ewes/ha) versus high (20 ewes/ha) stocking rate on liveweight gain per animal (g/animal/day) and per ha ( $\mathrm{kg} / \mathrm{ha} / \mathrm{day})$ over the total 46 day grazing period from 22 September to 7 November.

\begin{tabular}{lcccc}
\hline Liveweight gain & 10 ewes/ha & 20 ewes/ha & SED & $P$ \\
\hline Lambs & & & & \\
g/animal/day & 373.9 & 307.2 & 23.3 & 0.06 \\
kg/ha/day & 7.5 & 12.3 & 0.7 & $<0.01$ \\
Ewes & & & & \\
g/animal/day & 48.3 & -106.6 & 62.4 & 0.08 \\
kg/ha/day & 0.5 & -2.1 & 1.2 & 0.12 \\
\hline
\end{tabular}

Figure 2 The effect of low (10 ewes/ha) versus high (20 ewes/ha) stocking rate on pasture height of tall fescue ( $\square$ low, $\square$ high) and subterranean clover (O low, high) patches ( \pm SEM) measured with a rising plate meter.

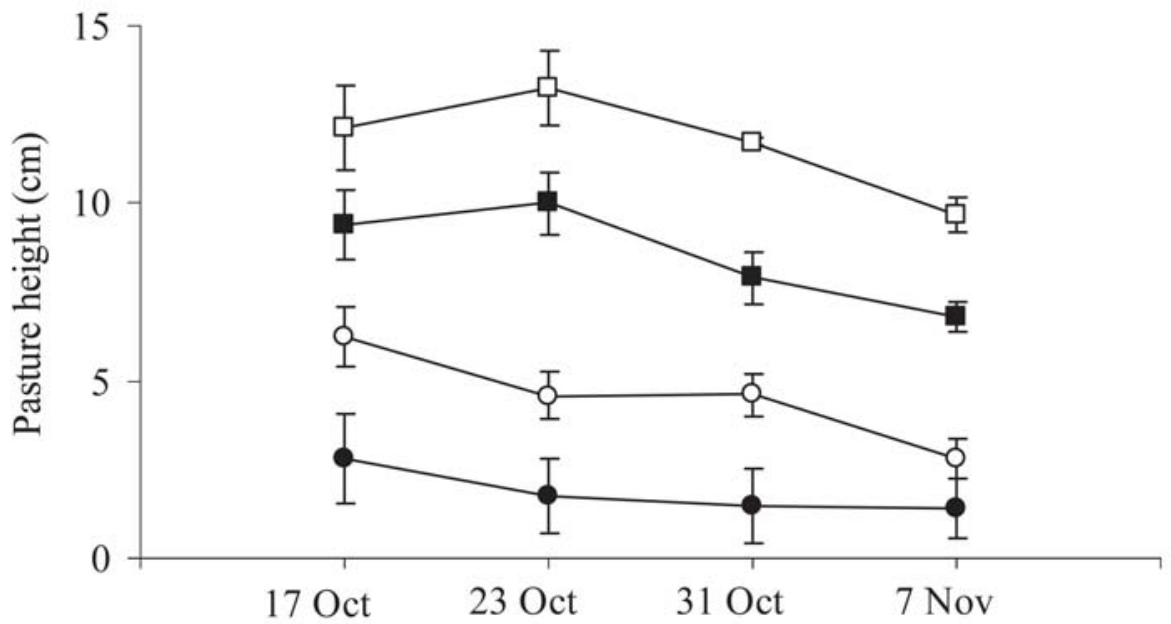


Table 2 The effect of low (10 ewes/ha) versus high (20 ewes/ha) stocking rate on botanical composition (\% cover) at the end of the grazing period.

\begin{tabular}{lccc}
\hline & 10 ewes/ha & 20 ewes/ha & $\mathrm{P}$ \\
\hline Tall fescue & 38.2 & 36.8 & 0.60 \\
Subterranean clover & 13.2 & 8.0 & 0.01 \\
Perennial clovers & 6.3 & 3.6 & 0.27 \\
Other annual legumes & 15.3 & 16.1 & 0.79 \\
Annual grasses weeds & 4.5 & 3.4 & 0.10 \\
Dicot weeds & 0.5 & 0.6 & 0.62 \\
Bare ground & 11.9 & 24.7 & 0.03 \\
Litter & 10.0 & 6.8 & 0.01 \\
\hline
\end{tabular}

Table 3 The effect of low (10 ewes/ha) versus high (20 ewes/ha) stocking rate on subterranean clover morphology, seed production in November 2005 and seedling numbers in March 2006.

\begin{tabular}{|c|c|c|c|c|}
\hline & 10 ewes/ha & 20 ewes/ha & SED & $\mathrm{P}$ \\
\hline Plant number $/ \mathrm{m}^{2}$ & 548 & 419 & 70.0 & 0.16 \\
\hline Runners/plant & 3.5 & 3.0 & 0.42 & 0.34 \\
\hline Runner length (mm/plant) & 147 & 78 & 10.4 & $<0.01$ \\
\hline Burrs/plant & 0.8 & 0.4 & 0.04 & $<0.01$ \\
\hline Inflorescences/plant ${ }^{1}$ & 1.2 & 0.7 & 0.02 & $<0.01$ \\
\hline Burrs $/ \mathrm{m}^{2}$ & 443 & 169 & 94.3 & 0.05 \\
\hline Dryweight/plant (mg) & 1.1 & 0.6 & 0.09 & 0.01 \\
\hline 1000 seed weight $(\mathrm{g})$ & 4.91 & 3.87 & 0.6 & 0.06 \\
\hline Seedlings $/ \mathrm{m}^{2}$ & 286 & 234 & 95.3 & 0.62 \\
\hline
\end{tabular}

Karridale seeds originally sown. Seedling numbers were low in both treatments in the following autumn (2006), but were not significantly different between grazing treatments (Table 3).

\section{Discussion}

\section{Ewe and lamb liveweight gain}

Twin lamb liveweight gains from this subterranean clover dominant pasture at the low ewe stocking rate of $374 \mathrm{~g} /$ head/day over 46 days compare favourably with the $407 \mathrm{~g} / \mathrm{head} /$ day over 84 days from twin lambs reported by Muir et al. (2003) from Poukawa, Hawkes Bay. In the Muir et al. (2003) study, ewes and rams were selected for high progeny growth rate and grazed a 6 month old autumn-established pasture of perennial ryegrass, white and subterranean clovers that were maintained at a pasture mass of $1800-2600 \mathrm{DM} / \mathrm{ha}$. The high liveweight gains reported in this study appear to reflect the high initial availability of subterranean clover (c. $40 \%$ from visual estimates) as the clumpy tall fescue population in the paddock, at 32 plants $/ \mathrm{m}^{2}$, was low and covered only about $35 \%$ of the ground area. Furthermore, the pasture would have been of high quality with subterranean clover leaf herbage having a similar nutritive value to that of white clover $(\mathrm{Ru} \&$ Fortune 2000).

The high stocking rate treatment reduced lamb liveweight gain relative to the low stocking rate treatment by $67 \mathrm{~g} /$ animal/day but ewe liveweight gain was reduced by $155 \mathrm{~g} / \mathrm{animal} /$ day with ewes at the high stocking rate losing weight (Table 1). This indicates that lambs in the high stocking rate benefited from the buffering effect of ewe body tissue mobilisation to maintain milk production. The low pasture height and low subterranean clover content in both stocking rate treatments in November (Fig. 2, Table 2) and the rapid weight loss of the high stocking rate ewes meant the experiment was concluded. In an ideal farm system, the high stocking rate flock would have been moved earlier to better feed in another paddock to avoid detrimental effects on clover reproduction and ewe liveweight loss. However, the maintenance of satisfactory lamb liveweight gain at both stocking rates through to early November indicates that sheep can reduce subterranean clover in grass-clover pastures to very small leafless plants (Tables $2 \& 3$ ) before large reductions in the rate of lamb liveweight gain are detected, and while green tall fescue remains on offer.

\section{Grazing effects on subterranean clover seed production}

The drier than average October resulted in the subterranean clover wilting about 4 weeks earlier than expected. By early November, subterranean clover plants in both stocking rates were reduced to small individuals (low stocking rate $=1.1 \mathrm{mg} \mathrm{DM} /$ plant, high stocking rate $=0.6 \mathrm{mg} \mathrm{DM} /$ plant) supporting less than two leaves per plant (Table 3). Moreover, seed 
production of these intensively grazed plants at both low and high stocking rates was substantially reduced (Table $3)$. The number of burrs $/ \mathrm{m}^{2}$ was reduced to 443 at the low stocking rate and to only 169 at the high stocking rate and, given the low weight of seed extracted from burrs collected from the soil surface in late summer, it is surprising that the seedling populations in autumn were over $200 / \mathrm{m}^{2}$ (Table 3). Clearly, the subterranean clover population in autumn 2006 suffered a significant reduction because of the dry conditions which resulted in over-grazing in late October-early November 2005, but the contribution of hard seed produced in spring 2004 to the March 2006 seedling populations may also have been substantial. Of note, however, is that the seedling populations in both treatments were below the recommended target numbers of 500-1000 seedlings $/ \mathrm{m}^{2}$ (Smetham 2003).

Final plant size in both grazing treatments was extremely small (Table 3). Visual observations during the last week indicated that there was little leaf left with the tips of most runners grazed off. This left few sites for burr formation ( $<1$ burr/plant) or leaf material to supply resources for seed development. Smetham \& Dear (2003) showed that hard grazing of subterranean clover monocultures resulted in large decreases in seed yield $(71 \mathrm{~kg} / \mathrm{ha}$ compared with 324 under lenient grazing). However, they showed that there were much smaller differences between lenient and hard grazing in mean herbage mass (1600 versus $1400 \mathrm{~kg} \mathrm{DM} / \mathrm{ha}$ ) than in leaf area index (1.1 and 0.7$)$. Thus it appears that to ensure moderate levels of seed production of subterranean clover, sheep should be removed before the leaf area index of the clover falls beneath 1.0 (i.e. one layer of leaves over the pasture area occupied by subterranean clover). As both stocking rate treatments in our grazing experiment had a leaf area index of less than 0.5 over the last 10 days in late October/early November it is not surprising that the seed production was low.
These stocking rate results obtained on the Canterbury plains are also relevant to summer dry hill country where sunny, north facing slopes dominated by annual legumes are often grazed hard during late spring. There, the objective would be to accumulate pasture mass on south faces where white clover may contribute more than annual clovers, so that some pastures on sunny faces may be spelled during subterranean clover late flowering-burr production.

\section{ACKNOWLEDGEMENTS}

We thank: The Turkish Ministry of Agriculture for funding the visit of Serkan Ates to Lincoln University; and Chris Logan, Nigel Jay, Colin Pettigrew and Alan Marshall for help with stock work.

\section{REFERENCES}

Costello, T; Costello, A. 2003. Subterranean clover in North Canterbury sheep pastures. Legumes for dryland pastures. Grassland Research and Practice Series 11: 189-192.

Muir, P.D.; Smith, N.B.; Lane, J.C. 2003. Maximising lamb growth rate - just what is possible in a high performance system. Proceedings of the New Zealand Grassland Association 65: 61-63.

$\mathrm{Ru}$, Y.J; Fortune, J.A. 2000. Effects of grazing intensity and cultivar on morphology, phenology and nutritive value of subterranean clover. II. Nutritive value during the growing season. Australian Journal of Agricultural Research 51: 1047-1055.

Smetham, M.L 2003. A review of subterranean clover (Trifolium subterraneum L.): its ecology and use as a pasture legume. Advances in Agronomy 79: 303-350.

Smetham, M.L.; Dear, B.S. 2003. The effect of continuous grazing on the seed production of subterranean clover (Trifolium subterraneum). Legumes for dryland pastures. Grassland Research and Practice Series 11: 155-160. 